\title{
The role of MGMT polymorphisms rs12917 and rs11016879 in head and neck cancer risk and prognosis
}

\author{
Paweł Kiczmer', Alicja Prawdzic Seńkowska1, Joanna Katarzyna Strzelczyk¹, Błażej Szydło, \\ Krzysztof Biernacki ${ }^{1}$, Tadeusz Osadnik2,3, Łukasz Krakowczyk ${ }^{4}$ and Zofia Ostrowska'
}

'Department of Medical and Molecular Biology, School of Medicine with the Division of Dentistry, Medical University of Silesia in Zabrze, Katowice, Poland; 22nd Department of Cardiology and Angiology, Silesian Center for Heart Disease, Zabrze, Poland; ${ }^{3 G}$ Genomics Laboratory, KardioMed Silesia Science and Technology Park, Zabrze, Poland; ${ }^{4}$ Department of Oncological and Reconstructive Surgery, Maria Sklodowska-Curie Memorial Cancer Center and Institute of Oncology, Gliwice Branch, Gliwice, Poland

Head and neck squamous cell carcinoma (HNSCC) is one of the leading cancers by incidence worldwide. The risk of these cancers is strictly associated with alkylation factors present in tobacco smoke. The crucial role in preventing DNA alkylation is played by 06-methylguanine-DNA methyltransferase (MGMT). Dysfunction or lack of MGMT is associated with an increased risk of cancer. The aim of the study was to assess the influence of MGMT polymorphisms: rs12917 and rs 11016879 on HNSCC risk and course. The study consisted of 69 HNSCC patients and 242 healthy individuals. Case samples were taken from resected tumour tissue. The control group comprised samples of epithelial cells collected from mucous membranes using swabs. DNA samples were genotyped by employing the $5^{\prime}$ nuclease assay for allelic discrimination using TaqMan SNP Genotyping Assays. The significance between distributions of genotypes and alleles was tested using Pearson's $X^{2}$ test analysis. Our results indicated that the MGMT rs12917 TT genotype increases the risk of HNSCC. The MGMT rs11016879 AG genotype and $A$ allele were associated with increased $\mathrm{HN}$ SCC risk. We noted higher risk of nodal metastasis in rs11016879 AA homozygotes. Mechanisms leading to MGMT enzymatic defect are unknown and hence further studies need to be carried out. Our data suggest that the examined polymorphisms may be considered as potential prognostic factors for HNSCC risk and outcome. Further studies are necessary to verify our results.

Key words: MGMT, head and neck cancer, polymorphism, rs12917, rs11016879

Received: 17 May, 2017; revised: 31 October, 2017; accepted: 18 December, 2017; available on-line: 25 January, 2018

e-mail: PKiczmer@wp.eu

Abbreviations: HNSCC, head and neck squamous cell carcinoma; MGMT, O6-methylguanine-DNA methyltransferase; HPV, human papilloma virus; SNP, single nucleotide polymorphism

\section{INTRODUCTION}

Head and neck squamous cell carcinoma (HNSCC) has received limited attention in recent years. Almost 540,000 new cases of HNSCC occur worldwide each year. The WHO predicts an increase of approximately $16 \%$ in the number of HNSCC cases by the year 2020. The risk of contracting this disease in both sexes is the highest after the age of 45 , and its incidence is 2- to 5-fold higher in men (Majchrzak et al., 2014).
HNSCC treatment is determined based on tumour stage characterization using the TNM scale. For tumours in I-II stage ( $\mathrm{T} 1 / 2, \mathrm{~N} 0)$, treatment consists of radiotherapy or surgery (Krzakowski \& Warzocha, 2013). The outcome at early stages varies, and a cure rate between $60 \%$ and $90 \%$ is observed. More advanced disease (T3/4 and/or N1-3) requires chemoradiotherapy or operation and radiotherapy and the outcome is poor, estimated as a $30 \%$ cure rate (Kordek et al., 2013).

Throughout their lives, humans are exposed to chemical substances, physical interactions or biological factors which may be classified as mutagens leading to carcinogenesis. There is a common belief that most HNSCC cases are caused by tobacco smoking and alcohol consumption. Cigarette smokers are 5- to 25-fold more prone to develop HNSCC compared to non-smokers (Marur \& Forastiere, 2008). Alcohol may influence the development of HNSCC as an independent factor as well as synergistically with tobacco use. On the other hand, an increased incidence of HNSCC in non-smokers and non-drinkers under 45 years of age has been observed. This phenomenon is attributed to human papillomavirus (HPV) (Majchrzak et al., 2014). Oncogenic HPV DNA has been observed in approximately $22 \%$ of oropharyngeal cancers (Ndiaye et al., 2014).

Apart from the environmental factors, we must consider molecular and genetic aspects of development of HNSCC. Human cells have evolved a large number of mechanisms to protect themselves from mutagenic agents, one example being the functioning of $\mathrm{O}^{6}$-methylguanine-DNA methyltransferase (MGMT). This enzyme prevents DNA alkylation by removing a methyl group from the O-6 position in guanine and transferring it to its own cysteine. Dysfunction or lack of MGMT is associated with an increased risk of contracting diseases including cancer (Shawney et al., 2012). The enzymatic activity may vary according to polymorphisms in its gene. The major MGMT polymorphism type is the single nucleotide polymorphism (SNP). In this study, we focused on two polymorphisms: rs12917 and rs11016879. rs12917 genotype involves conversion from cytosine to thymine. A Leu to Phe change at position 84 in the MGMT protein alters the enzyme substrate affinity and thus has been associated with a higher risk of cancer (Molina et al., 2013). The second polymorphism, rs11016879, is a conversion from adenine to guanine which is a synonymous substitution. Despite the enzyme structure 
not changing, synonymous SNPs may affect mRNA structure leading to allele-specific biological consequences (Shen et al., 1999). Some studies suggest that the synonymous substitution of one nucleotide may alter mRNA folding and decrease half-life resulting in downregulation of protein synthesis (Czech et al., 2010). On the other hand, it is suggested that replacement of certain synonymous codons could lead to the alteration of ribosome traffic on the mRNA at a selected position. Decreased protein synthesis may also be caused by asymmetric tRNA abundance leading to a delay in the rate of translation (Komar et al., 1999).

\section{MATERIALS AND METHODS}

Study population. This study was approved by the Institutional Review Board on Medical Ethics of the Maria Sklodowska-Curie Memorial Cancer Centre and Institute of Oncology in Gliwice (No KB/493-15/08 and $\mathrm{KB} / 430-47 / 13)$. We obtained written informed consent from all patients. We studied 69 patients with a primary tumour in the location of the oral cavity. Tissue samples were collected during surgical operation from patients with a previously untreated squamous cell carcinoma at the Department of Oncological and Reconstructive Surgery, Maria SklodowskaCurie Memorial Cancer Centre and Institute of Oncology, Gliwice, Poland. There were 49 men and 20 women, with a mean age of $56.07 \pm 9.81$ years (range: 29-73). Tumour staging was determined in accordance with TNM classification (Krzakowski \& Warzocha 2013). Nine of the patients $(13.04 \%)$ were in T1 stage, $14(20.29 \%)$ were in T2 stage, $16(23.19 \%)$ were in T3 stage and $30(43.47 \%)$ were in T4 stage. Moreover, 30 patients $(43.47 \%)$ were in N0 stage, $18(26.09 \%)$ were in N1 stage, $21(30.43 \%)$ were in N2 stage. 12 subjects $(17.39 \%)$ had G1, $49(68.12 \%)$ had G2, and 7 had G3 $(8.70 \%)$. None of the patients had received preoperative radio- or chemotherapy. The 5 year-survival rate was $59.09 \%$ among $>$ II TNM stage patients and $80 \%$ among patients in TNM stages I and II.

In the study group, $54(78.26 \%)$ subjects were smokers (current), $43(62.32 \%)$ reported alcohol intake. $38(55.07 \%)$ subjects reported both smoking and drinking and $23(33.33 \%)$ had previously had a cancer episode among first degree relatives.

The control group consisted of 242 (134 women and 108 men) healthy individuals. The mean age was $34.68 \pm 12.6$ years (range 18-87). $72(29.75 \%$ ) of them were smoking and $64(26.44 \%)$ reported alcohol intake. Epithelial cells were taken using swabs from the oral mucosa.

The Review Board on Medical Ethics of the Medical University of Silesia approved the study protocol (No KNW/0022/KB1/49/16). Informed consent was obtained from all participants.

DNA extraction. Genomic DNA was extracted from each sample of tumour tissues $(20 \mathrm{mg})$ using the DNeasy Blood \& Tissue Kit (Qiagen, USA) according to manufacturer's instructions, following homogenization of tissues using the FastPrep ${ }^{\circledR}-24$ instrument and Lysing Matrix A tubes (MP Biomedicals, USA).

We used the GeneMATRIX Swab-Extract DNA Purification Kit (EURx, Poland) to extract DNA from the control group individuals. Thereafter, the DNA was eluted in low salt buffer that contained $10 \mathrm{mM}$ Tris- $\mathrm{HCl}, \mathrm{pH} 8.5$.
Qualitative and quantitative analysis of the isolated DNA was performed by spectrophotometry. We used

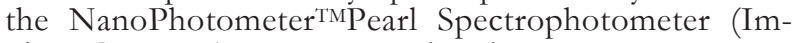
plen, Germany) to measure absorbance.

Genotyping. DNA samples were genotyped by employing the 5' nuclease assay for allelic discrimination using TaqMan ${ }^{\circledR}$ SNP Genotyping Assays. Purified DNA in a final concentration of $5 \mathrm{ng} / \mu \mathrm{l}$ was added to a MicroAmp ${ }^{\text {TM }}$ Optical 96-Well Reaction Plate (Applied Biosystems, USA). Each assay contained 11.25 $\mu \mathrm{l}$ DNA; $12.5 \mu \mathrm{l}$ TaqMan $^{\circledR}$ Genotyping Master Mix (Applied Biosystems, USA) and $1.25 \mu \mathrm{l}$ TaqMan $^{\circledR}$ Genotyping Assays (Applied Biosystems, USA). The genotyping was conducted in Cobas $z 480^{\circledR}$ Analyzer (Roche, USA). In $10 \%$ of the samples we repeated the procedure to verify the results.

In samples which were identified as homozygous and heterozygous (six samples representing each genotype) additionally we performed Sanger sequencing to confirm the genotype detected by TaqMan ${ }^{\circledR}$ SNP Genotyping Assays.

DNA sequencing. The sequence analysis of the selected PCR amplified fragments of the MGMT gene was carried out using ABI PRISM ${ }^{\circledR}$ BigDye $^{\circledR}$ Terminator v3.1 CycleSequencing Kit (Thermo Fisher, USA). The cycle sequencing was performed in SimpliAmp ${ }^{\mathrm{TM}}$ ThermalCycler (Thermo Fisher, USA). The separation of the PCR amplified fragments was conducted in 3130 Genetic Analyzer Applied Biosystems (Thermo Fisher, USA). The obtained data were managed in Applied Biosystems Sequencing Analysis Software (Thermo Fisher, USA) and further analysed in Thermo Fisher Applied Biosystems Variant Analysis (VA) Module. The analysis of MGMT gene fragment sequences in some of previously chosen samples confirmed the existence of the SNPs in the examined fragments.

Statistical analysis. The significance between distributions of genotypes and alleles was tested using Pearson's $\chi^{2}$ test analysis. We used non-parametric ANOVA analysis to examine the association of MGMT polymorphisms with grading, $\mathrm{T}$, and $\mathrm{N}$ parameters of the TNM classification. Logistic regression modelling was performed to analyse the 5-year survival including examined SNPs, age, grading, sex, tobacco, alcohol consumption and cancer episodes in family, regarding them as independent and coexisting factors. $P$ values $<0.05$ were considered as statistically significant. The statistical software STATISTICA 12 for Windows (STATSOFT, USA) was used to perform all analyses.

\section{RESULTS}

\section{Allele and genotype distributions}

The MGMT rs12917 T'T genotype was observed significantly more frequently in the HNSCC patients $(\mathrm{OR}=6.17$; 95\% CI 1.98-19.26) (Table 1). Rs12917 was not correlated with the risk of nodal infiltration (Table 2). We observed no association between rs12917 and tumour staging.

We found a significant association between the MGMT rs11016879 A allele and HNSCC risk $(\mathrm{OR}=2.00 ; 95 \%$ CI 1.05-3.83). Moreover, rs11016879 AG genotype significantly influenced HNSCC risk $(\mathrm{OR}=2.07$; 95\% CI 1.04-4.13) (Table 3). We noted that the rs11016879 AA genotype was more common 
Table 1. MGMT rs12917 polymorphism genotype frequency among groups

\begin{tabular}{lllllll}
\hline MGMT rs12917 & Cases $(\mathrm{n}=69)$ & \multicolumn{5}{c}{ Controls $(\mathrm{n}=239)$} \\
\hline Genotypes & $\mathrm{n}$ & $\%$ & $\mathrm{n}$ & $\%$ & $P$ value & OR (95\% Cl) \\
\hline CC & 49 & 71.01 & 168 & 70.29 & - & $1.00($ Reference) \\
\hdashline $\mathrm{CT}$ & 11 & 15.94 & 66 & 27.62 & 0.12 & $0.57(0.28-1.17)$ \\
\hdashline$\pi$ & 9 & 13.04 & 5 & 2.09 & 0.0005 & $6.17(1.98-19.26)$ \\
CT + TT & 20 & 28.99 & 71 & 29.71 & 0.91 & $0.97(0.54-1.74)$ \\
\hline
\end{tabular}

Table 2. Association between MGMT rs12917 polymorphism genotypes and risk of nodal metastases

\begin{tabular}{|c|c|c|c|c|c|c|}
\hline \multirow{2}{*}{$\begin{array}{l}\text { MGMT rs12917 } \\
\text { Genotypes }\end{array}$} & \multicolumn{2}{|c|}{ Nodes not involved $(n=30)$} & \multicolumn{4}{|c|}{ Nodes involved $(n=39)$} \\
\hline & $\mathrm{n}$ & $\%$ & $\mathrm{n}$ & $\%$ & $P$ value & OR $(95 \% \mathrm{Cl})$ \\
\hline CC & 22 & 73.33 & 27 & 69.23 & - & 1.00 (Reference) \\
\hline CT & 4 & 13.33 & 7 & 17.95 & 0.61 & $1.43(0.37-5.51)$ \\
\hline$\pi$ & 4 & 13.33 & 5 & 12.82 & 0.97 & $1.02(0.24-4.26)$ \\
\hline$C T+\pi$ & 8 & 26.67 & 12 & 30.77 & 0.71 & $1.23(0.42-3.52)$ \\
\hline
\end{tabular}

Table 3. MGMT rs11016879 polymorphism genotype frequency among groups

\begin{tabular}{lllllll}
\hline $\begin{array}{l}\text { MGMT } \\
\text { rs11016879 }\end{array}$ & Cases $(\mathrm{n}=66)$ & \multicolumn{2}{c}{ Controls $(\mathrm{n}=234)$} \\
\hline Genotypes & $\mathrm{n}$ & $\%$ & $\mathrm{n}$ & $\%$ & $P$ value & OR (95\% Cl) \\
\hline GG & 14 & 21.21 & 82 & 35.04 & - & $1.00($ Reference) \\
\hline AG & 34 & 51.52 & 96 & 41.03 & 0.04 & $2.07(1.04-4.13)$ \\
\hline AA & 18 & 27.27 & 56 & 23.93 & 0.11 & $1.88(0.87-4.09)$ \\
AA + AG & 52 & 78.79 & 152 & 64.96 & 0.03 & $2.00(1.05-3.83)$ \\
\hline
\end{tabular}

in patients with nodal metastases (Table 4); this association was statistically significant (OR=4.67; 95\% CI 1.01-21.65). Additionally, patients with rs11016879 A allele had significantly higher $\mathrm{N}$ parameter value (Fig. 1). We observed no association between rs11016879 and tumour staging.

No association between the coexistence of rs12917 and rs11016879 polymorphisms and HNSCC risk was observed. Neither MGMT rs12917 nor rs11016879 demonstrated an association with the $\mathrm{T}$ parameter and grading.

Due to the small number of I-II tumour stage cases, survival analysis was performed only for >II stage patients. We observed no influence of rs12917 or rs11016879 on the 5-year survival rate. A test for interaction between the examined SNPs, age, grading, sex, tobacco, alcohol consumption and cancer episodes in family, regarding them as independent and coexisting factors, using the logistic regression model for survival rate, was not significant.

\section{DISCUSSION}

Head and neck cancers are an important clinical issue. These lesions are difficult to cure, especially because of their location. Surgical operations are limited by the complexity of important anatomical structures in the regions of the cancer. Furthermore, proximity to the central nervous system and eyes limits radiotherapy (Bartkowski 1996; Ziółkowska 2011).

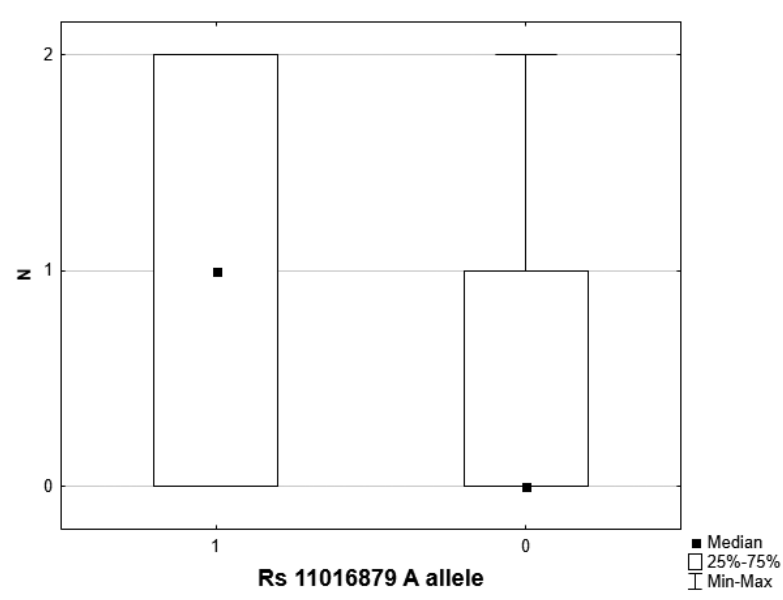

Figure 1. Association of the rs11016879 A allele genotype with the $\mathrm{N}$ parameter ( $p=0.048$, Mann-Whitney $\mathrm{U}$ test)

MGMT rs12917 $\mathrm{T}$ allele is commonly associated with an overall increased risk of cancer. It has also been suggested that the $\mathrm{T}$ allele may increase the risk of non-small cellular lung cancer (Du et al., 2013). However, its role in HNSCC remains unclear; Zhang et al., found no correlation between rs12917 and HNSCC risk (Zhang et al., 2010). In our study MGMT rs12917 polymorphism may be considered as a risk 
Table 4. Association between MGMT rs11016879 polymorphism genotypes and risk of nodal metastases

\begin{tabular}{lllllll}
\hline MGMT rs1 1016879 & Nodes not involved $(\mathrm{n}=26)$ & \multicolumn{3}{l}{ Nodes involved $(\mathrm{n}=40)$} & \\
\hline Genotypes & $\mathrm{n}$ & $\%$ & $\mathrm{n}$ & $\%$ & $P$ value & OR $(95 \% \mathrm{Cl})$ \\
\hline GG & 8 & 30.77 & 6 & 15.00 & - & $1.00($ Reference) \\
\hdashline AG & 14 & 53.85 & 20 & 50.00 & 0.31 & $1.90(0.54-6.71)$ \\
\hdashline AA & 4 & 15.38 & 14 & 35.00 & 0.04 & $4.67(1.01-21.65)$ \\
AA+AG & 18 & 69.23 & 34 & 85.00 & 0.13 & $2.52(0.76-8.39)$ \\
\hline
\end{tabular}

factor for HNSCC. We observed a significant association between rs12917 TT genotype and risk of HNSCC. In contrast, a different study has demonstrated that the $\mathrm{T}$ allele may decrease head and neck cancer risk (Hall et al., 2007). Moreover, the same researchers have suggested a protective role of another interesting polymorphism, rs2308321, whereas most other studies have determined a negative influence of this SNP. It is commonly known that rs 12917 is associated with an increased risk of lung cancer and may be responsible for the increased risk of oesophageal cancer (Doecke et al., 2008; Du L et al., 2013; Qui et al., 2014).

There is only one publication describing the association between the rs11016879 polymorphism and cancer risk, specifically oesophageal squamous cell carcinoma. The study demonstrated that increased oesophageal cancer risk is related to the rs11016879 A allele ( $\mathrm{Ma}$ et al., 2010). Other studies suggest no association between this SNP and renal cancer risk (Lee Moore et al., 2009). According to our knowledge, our study is the first to describe the influence of rs11016879 on HNSCC risk. We found a significant association between AG genotype and A allele and HNSCC risk. Moreover, this is the first study examining the influence of the rs11016879 genotype on the risk of nodal metastases. Our study provides information about the association between the AA genotype of this polymorphism and increased risk of nodal metastases. Involved lymph nodes are a prognostic factor for HNSCC recurrence (Burusapat et al., 2015; Leemans et al., 1994). Patients with nodal metastases require adjuvant treatment. Analysis of nodal metastases risk factors may improve the survival rate. The MGMT rs11016879 genotype may be considered as a nodal infiltration risk factor. Further studies are needed to determine the clinical utility of this SNP as an independent risk factor of nodal metastases. Our results demonstrated for the first time that rs11016879 may be associated with a poor prognosis of head and neck cancers, however, we observed no influence of rs11016879 on the 5-year survival rate. These results are compatible with those from the study by Wibom and coworkers which suggest no association between this SNP and glioblastoma survival (Wibom et al., 2012).

Rs12917 and rs2308321 MGMT polymorphisms are situated near the enzyme active site, thus affecting molecular activity (Egyhazi et al., 2002; Sharma et al., 2009). Some researchers suggest that rs12917 may influence $\mathrm{Zn}^{2+}$ binding ability leading to changes in MGMT enzymatic activity (Sharma et al., 2009). Some SNPs, such as rs11016879, are silent mutations that do not change the amino acid sequence. However, this may affect MGMT activity. Dysfunction of MGMT enzyme may lead to carcinogenesis. MGMT activity may be affected by the methylation of its promoter, thereby lowering its expression (Sharma et al., 2009). Smoking is suggested to be one of the inducing factors of low transcription of MGMT at the epigenetic level (Strzelczyk et al., 2016). Activity of this enzyme may vary according to its polymorphisms (SNPs). Moreover, some polymorphisms influence the expression of MGMT by increasing promoter methylation (Fogli et al., 2016). Sawnhey et al., observed that increased risk of nodal infiltration is associated with MGMT methylation in oral cancer (Sawhney et al., 2012). Additionally, Yu and coworkers demonstrated that MGMT methylation increases the risk of nodal metastases in gastric cancer (Yu et al., 2016).

Nonetheless, lowered MGMT activity may have a positive influence on cytostatic treatment. This is because of the mechanism of action of alkylating drugs that damage DNA leading to cell death. Previous studies have reported a higher survival rate in glioblastoma patients with lower MGMT expression caused by methylation during temozolomide treatment (Rapkins et al., 2015). However, some studies suggest that MGMT hypermethylation has no influence on the chemotherapy response in laryngeal cancer (Onerci Celebi et al., 2016). Other researchers reported that MGMT activity does not act as a resistance factor for radiochemotherapy (Jacob et al., 2010).

Modifiable environmental factors, such as alcohol or smoking, strongly affect the HNSCC risk (Hashibe et al., 2009; Sharma et al., 2009). It is worth mentioning that tobacco and alcohol jointly have a greater than multiplicative effect on HNSCC risk (Maier et al., 1992). Tobacco smoke contains large amounts of harmful substances, the individual effects of which are difficult to assess at the molecular level because this complex mixture of carcinogens, tumour growth promoters, and cocarcinogens manifests its effects upon chronic exposure (Pfeifer et al., 2002). Alkylating factors are an example of cancerogenous agents present in tobacco smoke. These substances damage DNA through the addition of alkyl groups (Jacob et al., 2010). Humans have developed several mechanisms for protection against alkylating factors. The primary role in this defence is played by MGMT (Shawney et al., 2012).

In our study, we observed no significant interactions between modifiable environmental factors, cancer episodes in family, staging, grading and the examined SNPs for the 5-year survival in the logistic regression model. It should be emphasized that we were the first to compare these parameters with rs12917 and rs11016879. However, our study was limited by small sample size.

In conclusion, MGMT rs12917 polymorphism may be associated with increased risk of HNSCC. However, this SNP does not affect prognosis. On the 
other hand, the MGMT rs11016879 polymorphism is both related to cancer risk and may affect prognosis. To determine the clinical consequences of examined SNPs on HNSCC risk and prognosis and to confirm our results, further studies, comprising greater sample sizes, are needed to be performed. Mechanisms leading to MGMT enzymatic defect remain to be clarified. We believe, that analysis of MGMT gene polymorphism may provide novel insights for cancer prediction in the near future.

\section{REFERENCES}

Bartkowski, SB (1996) Chirurgia szczękowo-twarzowa. Ages, Kraków 33-34 (in Polish)

Burusapat C, Jarungroongruangchai W, Charoenpitakchai M (2015) Prognostic factors of cervical node status in head and neck squamous cell carcinoma. World J Surg Oncol 13: 51. https://doi. org/10.1186/s12957-015-0460-6

Czech A, Fedyunin I, Zhang G, Ignatova Z (2010) Silent mutations in sight: Co-variations in tRNA abundance as a key to unravel consequences of silent mutations. Molecular BioSyst 6: 1767-1772

Doecke J, Zhao ZZ, Pandeya N, Sadeghi S, Stark M, Green AC, Hayward NK, Webb PM, Whiteman DC (2008) Polymorphisms in MGMT and DNA repair genes and the risk of esophageal adenocarcinoma. Int J Cancer 123: 174-180. http://dx.doi.org/10.1002/ ijc. 23410

Du L, Wang H, Xiong T, Ma Y, Yang J, Huang J, Zeng D, Wang X, Huang $H$ (2013) The polymorphisms in the MGMT gene and the risk of cancer. A meta-analysis. Tumour Biol 34: 3227-3237. http:// dx.doi.org/10.1007/s13277-013-0893-x

Egyhazi S, Ma S, Smoczynski K, Hansson J, Platz A, Ringborg U (2002) Novel O6-methylguanine-DNA methyltransferase SNPs: a frequency comparison of patients with familial melanoma and healthy individuals in Sweden. Hum Mutat 20: 408-409. http:// dx.doi.org/10.1002/humu.9078

Fogli A, Chautard E, Vaurs-Barriere C, Pereira B, Muller-Barthelemy M, Court F, Biau J, Pinto AA, Kemeny J-L, Khalil T, KarayanTapon L, Verrelle P, Costa BM, Arnaud P (2016) The tumoral A genotype of the MGMT rs34180180 single-nucleotide polymorphism in aggressive gliomas is associated with shorter patients' survival. Carcinogenesis 37: 169-176. http://dx.doi.org/10.1093/carcin/bgv251

Hall J, Hashibe M, Boffetta P, Gaborieau V, Moullan N, Chabrier A, Zaridze D, Shangina O, Szeszenia-Dabrowska N, Mates D, Janout V, Fabianova E, Holcatova I, Hung RJ, McKay J, Canzian F, Brennan P (2007) The association of sequence variants in DNA repair and cell cycle genes with cancers of the upper aerodigestive tract. Carcinogenesis 28: 665-671. http://dx.doi.org/10.1093/carcin/bgl160

Hashibe M, Brennan P, Chuang S-C, Boccia S, Castellsague X, Chen C, Curado MP, Dal Maso L, Daudt AW, Fabianova E, Fernandez L, Wunsch-Filho V, Franceschi S, Hayes RB, Herrero R, Kelsey K, Koifman S, La Vecchia C, Lazarus P, Levi F, Lence JJ, Mates D, Matos E, Menezes A, McClean MD, Muscat J, Eluf-Neto J, Olshan AF, Purdue M, Rudnai P, Schwartz SM, Smith E, Sturgis EM, Szeszenia-Dabrowska N, Talamini R, Wei Q, Winn DM, Shangina O, Pilarska A, Zhang Z-F, Ferro G, Berthiller J, Boffetta P (2009) Interaction between tobacco and alcohol use and the risk of head and neck cancer. Pooled analysis in the International Head and Neck Cancer Epidemiology Consortium. Cancer Epidemiology, Biomarkers Prev 18: 541-550. http://dx.doi.org/10.1158/1055-9965.EPI-080347

Huang W-Y, Olshan AF, Schwartz SM, Berndt SI, Chen C, Llaca V, Chanock SJ, Fraumeni JF, Hayes RB (2005) Selected genetic polymorphisms in MGMT, XRCC1, XPD, and XRCC3 and risk of head and neck cancer: A pooled analysis. Cancer Epidemiol Biomarkers Prev 14: 1747-1753. http://dx.doi.org/10.1158/1055-9965.EPI-05-0162

Jacob R, Shafiei N, Nagel G, Welkoborsky HJ, Mann W, Kaina B (2010) MGMT activity in mucosal epithelium and squamous cell carcinoma of the head and neck. Anticancer Res 30: 2561-2566

Kimchi-Sarfaty C, Oh JM, Kim I-W, Sauna ZE, Calcagno AM, Ambudkar SV, Gottesman MM (2007) A "silent" polymorphism in the MDR1 gene changes substrate specificity. Science 315: 525-528. http://dx.doi.org/10.1126/science. 1135308

Komar AA, Lesnik T, Reiss C (1999) Synonymous codon substitutions affect ribosome traffic and protein folding during in vitro translation. FEBS Lett 462: 387-391. http://dx.doi.org/10.1016/S00145793(99)01566-5

Kordek R, Jassem J, Jeziorski A, Kornafel J, Krzakowski M, Pawlęga J (2013) Onkologia. Podręcznik dla studentów. Via Medica, Gdańsk, 2013. 146-157 (in Polish)

Kreimer AR, Clifford GM, Boyle P, Franceschi S (2005) Human papillomavirus types in head and neck squamous cell carcinomas world- wide: a systematic review. Cancer Epidemiol Biomarkers Prev 14: 467475. http://dx.doi.org/10.1158/1055-9965.EPI-04-0551

Krzakowski M, Warzocha K (2013) Nowotwory nabłonkowe narządów głowy i szyi. In: Zalecenia postępowania diagnostyczno-terapeutycznego w nowotworach złośliwych. 2013 Via Medica, Gdańsk 5-13 (in Polish)

Lee Moore, Brennan P, Karami S, Menashe I, Berndt SI, Dong LM, Meisner A, Yeager M, Chanock S, Colt J, Schwartz K, Davis F, Zaridze D, Mattveev V, Janout V, Kollarova H, Bencko V, Navratilova M, Szeszenia-Dabrowska N, Mates D, Holcatova I, Boffetta P, Chow WH, Rosenberg PS, Rothman N (2009) Apolipoprotein E/C1 locus variants modify renal cell carcinoma risk. Cancer Res 69 : 8001-8008 (Suppl 1). http://dx.doi.org/10.1158/0008-5472.CAN$09-1734$

Leemans CR, Tiwari R, Nauta JJP, Waal IVD, Snow GB (1994) Recurrence at the primary site in head and neck cancer and the significance of neck lymph node metastases as a prognostic factor. Cancer 73: 187-190. doi:10.1002/1097-0142(19940101)73:1<187::AIDCNCR2820730132>3.0.CO;2-J

Ma W-J, Lv G-D, Zheng S-T, Huang C-G, Liu Q, Wang X, Lin R-Y, Sheyhidin I, Lu X-M (2010) DNA polymorphism and risk of esophageal squamous cell carcinoma in a population of North Xinjiang, China. World J Gastroenterol 16: 641-647

Maier H, Dietz A, Gewelke U, Heller WD, Weidauer H (1992) Tobacco and alcohol and the risk of head and neck cancer. Clin Investig 70: $320-327$

Majchrzak E, Szybiak B, Wegner A, Pienkowski P, Pazdrowski J, Luczewski L, Sowka M, Golusinski P, Malicki J, Golusinski W (2014) Oral cavity and oropharyngeal squamous cell carcinoma in young adults: a review of the literature. Radiol Oncol 48: 1-10. http:/9 dx.doi.org/10.2478/raon-2013-0057

Marur S, Forastiere AA (2008) Head and neck cancer: changing epidemiology, diagnosis, and treatment. Mayo Clinic Proc 83: 489-501. http://dx.doi.org/10.4065/83.4.489

Molina E, Perez-Morales R, Rubio J, Petrosyan P, Cadena LH, Arlt V M, Phillips DH, Gonsebatt ME (2013) The GSTM1 null (deletion) and MGMT84 rs12917 (Phe/Phe) haplotype are associated with bulky DNA adduct levels in human leukocytes. Mutat Res 758: 62-68. http://dx.doi.org/10.1016/j.mrgentox.2013.09.007

Ndiaye C, Mena M, Alemany L, Arbyn M, Castellsagué X, Laporte L, Bosch FX, Sanjosé S de, Trottier H (2014) HPV DNA, E6/E7 mRNA, and p16INK4a detection in head and neck cancers. A systematic review and meta-analysis. The Lancet Oncology 15: 1319-1331. http:/ /dx.doi.org/10.1016/S1470-2045(14)70471-1

Onerci Celebi O, Tezel GG, Hosal AS, Cenquiz M, Gullu IH, Hayran M (2016) Detection of O6-methylguanine-DNA methyltransferase gene promoter region methylation pattern using pyrosequencing and the effect of methylation pattern on survival, recurrence, and chemotherapy sensitivity in patients with laryngeal cancer. Pathol Res Pract 212: 456-62. https://doi.org/10.1016/j.prp.2016.02.022

Pfeifer GP, Denissenko MF, Olivier M, Tretyakova N, Hecht SS, Hainaut P (2002) Tobacco smoke carcinogens, DNA damage and p53 mutations in smoking-associated cancers. Oncogene 21: 7451. http:// dx.doi.org/10.1038/sj.onc.1205803

Qiu ZX, Xue F, Shi XF, He X, Ma HN, Chen L, Chen PZ (2014) MGMT Leu84Phe gene polymorphism and lung cancer: a meta analysis. Tumor Biol 35: 4381-4387. https://doi.org/10.1007/s13277013-1576-3

Ragin CCR, Modugno F, Gollin SM (2007) The epidemiology and risk factors of head and neck cancer: a focus on human papillomavirus. J Dent Res 86: 104-114

Rapkins RW, Wang F, Nguyen HN, Cloughesy TF, Lai A, Ha W, Nowak AK, Hitchins MP, McDonald KL (2015) The MGMT promoter SNP rs16906252 is a risk factor for MGMT methylation in glioblastoma and is predictive of response to temozolomide. Neuro oncol 17: 1589-1598. http://dx.doi.org/10.1093/neuonc/nov064

Sawhney M, Rohatgi N, Kaur J, Gupta SD, Deo SV, Shukla NK and Ralhan R (2012) MGMT expression in oral precancerous and cancerous lesions. Correlation with progression, nodal metastasis and poor prognosis. Oral Oncology 43: 515-522. http://dx.doi. org/10.1016/j.oraloncology.2006.05.007

Sharma S, Salehi F, Scheithauer BW, Rotondo F, Syro LV, Kovacs K (2009) Role of MGMT in tumor development, progression, diagnosis, treatment and prognosis. Anticancer Res 29: 3759-3768. http:// dx.doi.org/

Shen LX, Basilion JP, Stanton VP Jr (1999) Single-nucleotide polymorphisms can cause different structural folds of mRNA. Proc Natl Acad Sci U S A 96: 7871-7876. http://dx.doi.org/

Strzelczyk JK, Golabek K, Krakowczyk L, Owczarek AJ (2016) Expression profiles of $M G M T, p 16$, and $A P C$ genes in tumor and matching surgical margin from patients with oral squamous cell carcinoma. Acta Biochim Pol 63: 505-509. http://dx.doi.org/10.18388/ abp.2015_1204

Wibom C, Sjostrom S, Henriksson R, Brannstrom T, Broholm $\mathrm{H}$ Ryden P, Johansen C, Collatz-Laier H, Hepworth S, McKinney PA, Bethke L, Houlston RS, Andersson U, Melin BS (2012) DNA-repair 
gene variants are associated with glioblastoma survival. Acta Oncol 51: 325-332. http://dx.doi.org/10.3109/0284186X.2011.616284

Yu D, Cao T, Han Y-D, Huang F-S (2016) Relationships between MGMT promoter methylation and gastric cancer. A meta-analysis. OncoTargets and Therapy 9: 6049-6057. http://dx.doi.org/10.2147/ OTT.S114052

Zhang Z, Wang L, Wei S, Liu Z, Wang LE, Sturgis EM, Wei Q (2010)

Polymorphisms of the DNA repair gene MGMT and risk and progression of head and neck cancer. DNA Repair 9: 558-566. https:// dx.doi.org/10.1016\%2Fj.dnarep.2010.02.006
Zhong Y, Huang Y, Huang Y, Zhang T, Ma C, Zhang S, Fan W, Chen H, Quian J, Lu D (2010) Effects of O6-methylguanine-DNA methyltransferase (MGMT) polymorphisms on cancer: a meta-analysis. Mutagenesis 25: 83-95. https://doi.org/10.1093/mutage/gep050

Ziółkowska E, Biedka M, Windorbska W (2011) Odczyn popromienny u chorych na raka region głowy I szyi: mechanizmy I konsekwencje. Otolaryngologia 10: 147-153 (in Polish) 